\title{
Comparison of Adansonian Analysis and Deoxyribonucleic Acid Hybridization Results in the Taxonomy of Yersinia enterocolitica
}

\author{
SYDNEY HARVEY AND M. J. PICKETT \\ Department of Microbiology, University of California, Los Angeles, California 90024
}

\begin{abstract}
A total of 190 strains of Yersinia enterocolitica from environmental sources, humans, and other animals were scored on biochemical, nutritional, and resistance tests. These were run in duplicate at 30 and $35^{\circ} \mathrm{C}$, and the results were analyzed by numerical taxonomy. The computer-generated phenograms derived from simple matching coefficients and unweighted average linkage analysis delineated seven phenons from the $30^{\circ} \mathrm{C}$ data and five phenons from the $35^{\circ} \mathrm{C}$ data at a similarity value of $85 \%$. A centrostrain was derived from each cluster in both matrixes, and these centrostrains were used as reference strains for subsequent deoxyribonucleic acid hybridizations. The relative binding ratios of the centrostrains to one another, as well as to other organisms of their own phenons, were determined. The genetic relationships as denoted by relative binding ratios were compared with the phenetic relationships developed by numerical taxonomy. Our results demonstrate that taxonomic relationships generated by numerical taxonomy do not necessarily correlate highly with those derived by deoxyribonucleic acid hybridizations in either a linear or a numerical sense (correlation coefficients, 0.48 and 0.40 ; mean correlation ratio, 0.60 ). In addition, it was found that numerical taxonomies may show considerable fluctuations in phenomic composition, which are dependent on the temperature of incubation. Deoxyribonucleic acid hybridizations among the various strains of this study divided the species $Y$. enterocolitica into at least four deoxyribonucleic acid relatedness groups. The level of intergroup homology was high enough (relative binding ratio, $>20 \%$ ) to justify the inclusion of all groups as species in the genus Yersinia.
\end{abstract}

The majority of bacterial taxonomists presently base their classification schemes on one of two techniques: numerical taxonomy and deoxyribonucleic acid (DNA) hybridizations. Each procedure has its ardent adherents. Only rarely have both procedures been used together, and, to our knowledge, there has never been a comparative evaluation of the relative correlation of the two techniques. Since the taxonomy of Yersinia enterocolitica had not been resolved and since we had isolated many environmental strains (10) whose relationship to this species was unclear, the opportunity to do several interrelated taxonomic studies presented itself.

Thus, a tripartite study was initiated, using a heterogeneous collection of organisms, all of which had been identified as members of $Y$. enterocolitica. The primary objective was to determine what correlation, if any, exists between phenetic analysis and genetic analysis when each is applied to the same group of organisms for the purpose of developing taxonomic relationships. A necessary prerequisite to this project (and a discrete study in itself) was the development of two numerical taxonomies, one with tests incubated at $35^{\circ} \mathrm{C}$ and one with tests incubated at $30^{\circ} \mathrm{C}$. This $5^{\circ} \mathrm{C}$ difference in incubation temperature served two purposes: (i) to provide a lower (and thus perhaps a more nearly optimum) temperature of incubation for Y. enterocolitica than $35^{\circ} \mathrm{C}$ (reports in the literature $[14,21]$ suggest that temperatures from 22 to $30^{\circ} \mathrm{C}$ are more conducive to growth of $Y$. enterocolitica than are higher temperatures), and (ii) to assess the intrinsic error in a taxonomic system which relies on the expression of phenotypic characteristics which may be affected by even a slight change in incubation temperature. The third objective was to determine the genetic relationships of the environmental strains of $Y$. enterocolitica to each other and to strains from humans and from other animals in order to render an opinion as to their species status.

\section{MATERIALS AND METHODS}

Numerical taxonomy. (i) Bacterial strains. A total of 190 strains of $Y$. enterocolitica and $Y$. enterocolitica-like organisms and 5 non-Yersinia control organisms was used in the study. In addition to our own 66 isolates identified as strains of $Y$. enterocolitica 
(62 from environmental sources, 3 from rodents, and 1 from a human), 124 strains were contributed by a variety of individuals. This collection encompassed isolates from humans, other animals, and environmental sources and included all presently classified biovars. The five non-Yersinia control organisms were Pseudomonas fluorescens Ps 19, Enterobacter ag. glomerans Ea 42, Citrobacter diversus Y-U, and two strains of unidentified oxidase-negative water organisms. In addition to these non-Yersinia control organisms, three pairs of $Y$. enterocolitica strains were included as intrinsic controls. One pair was a duplicate subculture of a single colony, whereas one member of each of the other pairs was a lactose-positive variant of an original lactose-negative strain. The designations and sources of all of the strains studied are listed in Table 1. To promote objectivity during scoring of the results, each strain was handled unnamed under a serial number (throughout this paper strain numbers refer to these serial numbers).

During the study, all stock strains were maintained on Kligler iron agar (Difco Laboratories). The stock organisms were subcultured every 4 to 5 months and were stored at $4^{\circ} \mathrm{C}$.

For all test medium inoculations with the exception of single-carbon-source replica plates, working cultures were 18- to 24-h-old heart infusion broth (Difco) cultures incubated at the appropriate test temperature. One standard loopful of this broth culture was used as inoculum. Replica plate inoculation was done with three 72-grid templates prepared on heart infusion agar (Difco) incubated for 18 to $24 \mathrm{~h}$ at the appropriate test temperature.

(ii) Media. All media were used within 5 days of preparation. Every batch of medium was made in a volume sufficient for testing the 195 organisms. The standard procedure was to inoculate all 195 organisms onto two to four sets of different test media within 1 day. Because of the uniform inoculation of the whole group of organisms onto a single batch of medium, any error inherent in doing the tests piecemeal was avoided.

(iii) Growth tests. The ability of the organisms to utilize single carbon sources for growth was tested on a basal medium containing $1.0 \mathrm{~g}$ of $\mathrm{NH}_{4} \mathrm{Cl}, 2.14 \mathrm{~g}$ of $\mathrm{Na}_{2} \mathrm{HPO}_{4} \cdot 2 \mathrm{H}_{2} \mathrm{O}, 1.09 \mathrm{~g}$ of $\mathrm{KH}_{2} \mathrm{PO}_{4}, 0.2 \mathrm{~g}$ of $\mathrm{MgSO}_{4}$. $7 \mathrm{H}_{2} \mathrm{O}, 10 \mathrm{ml}$ of trace salts solution, $15.0 \mathrm{~g}$ of agar, and 1 liter of distilled water. The trace salts solution contained $300 \mathrm{mg}$ of $\mathrm{FeSO}_{4} \cdot 7 \mathrm{H}_{2} \mathrm{O}, 180 \mathrm{mg}$ of $\mathrm{MnCl}_{2}$. $4 \mathrm{H}_{2} \mathrm{O}, 130 \mathrm{mg}$ of $\mathrm{Co}\left(\mathrm{NO}_{3}\right)_{2} \cdot 6 \mathrm{H}_{2} \mathrm{O}, 1,000 \mathrm{mg}$ of $\mathrm{CaCl}_{2}$, and 1 liter of $0.1 \mathrm{~N} \mathrm{HCl}$. The trace salts solution was added to the base before autoclaving, the medium was cooled, and a presterilized carbon source (final concentration, $0.1 \%$, wt/vol) was added. Growth was recorded at $24 \mathrm{~h}$ and 7 days. Plates without carbon source served as controls for background growth. Heart infusion agar plates were included to check bacterial viability after the last plate in a series was stamped. No more than four test plates plus controls were included in any run. The carbon sources tested were acetate, benzoate, butyrate, glycerate, lactate, malate, malonate, nicotinate, phenylacetate, propionate, pyruvate, succinate, tartrate, valerate, adonitol, amygdalin, arabinose, $d$-arabitol, $l$-arabitol, cellobiose, erythritol, galactose, myo-inositol, lactose, maltose, man- nose, melezitose, melibiose, raffinose, rhamnose, salicin, sorbose, sorbitol, trehalose, xylose, alanine, $\beta$-alanine, glutamate, glycine, histidine, hydroxy-L-proline, ornithine, serine, benzylamine, glucosamine, hippurate, histamine, putrescine, sarcosine, betaine, 1,3-butanediol, creatine, ethanol, galacturonate, geraniol, glycerol, pectin, and trigonelline.

The ability of the organisms to grow in heart infusion broth at $\mathrm{pH} 4.0,4.5,5.0,6.0,8.0$, and 9.0 was recorded at $24 \mathrm{~h}$ and 7 days.

Growth in the presence of $\mathrm{NaCl}$ incorporated in nutrient broth (Difco) at concentrations of $3,4,5,6$, $6.5,7$, and $7.5 \%$ (wt/vol) was tested. Bacteria were also inoculated into nutrient broth alone as a control. Growth was recorded at $24 \mathrm{~h}$ and 7 days.

Growth of the organisms on various selective media was tested. The following dehydrated selective media were prepared according to the directions of the manufacturers: MacConkey agar (Difco), deoxycholate citrate agar (Oxoid), Hektoen agar (BBL Microbiology Systems), xylose lysine Desoxycholate agar (BBL), salmonella-shigella agar (BBL), brilliant green agar (Difco), mannitol salt agar (Difco), and cetrimide agar (BBL). Triphenyl tetrazolium chloride at 0.001 and $0.01 \%(\mathrm{wt} / \mathrm{vol}$ ) was incorporated in heart infusion agar before autoclaving, as were $0.05 \%$ (wt/vol) sodium azide and 1.0 and $1.5 \%$ (wt/vol) sodium deoxycholate. Growth was recorded at $24 \mathrm{~h}$ and 7 days.

The ability of the organisms to grow at $42^{\circ} \mathrm{C}$ in heart infusion broth was determined visually after incubation in a water bath. Readings were made every $24 \mathrm{~h}$ for 7 days.

(iv) Production of acid from carbohydrates. A basal medium composed of $1.0 \%$ (wt/vol) Casitone (Difco), 0.001\% (wt/vol) bromocresol purple, and distilled water was dispensed in 3-ml amounts into test tubes ( 13 by $100 \mathrm{~mm}$ ) containing Durham vials. After autoclaving, the medium was cooled, and $0.15 \mathrm{ml}$ of the appropriate prefiltered carbohydrate $(20 \%$, wt/vol) was aseptically added to each tube. Tubes were scored for acid and gas formation at $24 \mathrm{~h}$ and 4 days. The carbohydrates tested were adonitol, amygdalin, $d$-arabinose, $l$-arabinose, arbutin, cellobiose, dulcitol, galactose, glucose, fructose, inositol, inulin, lactose, maltose, mannitol, raffinose, rhamnose, ribose, salicin, sorbitol, sucrose, trehalose, and xylose.

(v) Miscellaneous tests. Urease activity was detected in Christensen medium (4). Alkalinization of the medium was noted at 24-h intervals for 4 days. Hydrolysis of esculin was observed as a blackening of bile esculin medium (Difco). The medium was prepared and inoculated as described in the directions of the manufacturer, except that serum was omitted.

The tartrate medium of Jordan and Harmon (13) was used for the detection of acid production from tartrate. Any definite yellow color in the medium was scored as a positive result.

Heart infusion agar supplemented after autoclaving with $5 \%$ sterile human or sheep blood served as the substrate for the observations of hemolytic activity. The presence or absence of hemolysis was noted only around single colonies.

For the detection of deoxyribonuclease activity, dehydrated medium (Difco) was prepared according to the directions of the manufacturer. Development of a 
TABLE 1. List of strains used in this study

\begin{tabular}{|c|c|c|c|c|c|c|}
\hline \multirow[b]{2}{*}{ Serial no. } & \multicolumn{2}{|c|}{ Received as: } & \multicolumn{2}{|c|}{ Biovar $^{a}$} & \multirow[b]{2}{*}{ Source $^{h}$} & \multirow[b]{2}{*}{ Habitat } \\
\hline & Species & $\begin{array}{c}\text { Strain designa- } \\
\text { tion }\end{array}$ & Rhamnose & Sucrose & & \\
\hline 1 & Y. enterocolitica & Ye 1 & + & + & 1 & Environmental \\
\hline 2 & Y. enterocolitica & Ye 2 & + & - & 1 & Environmental \\
\hline 3 & Y. enterocolitica & Ye 3 & - & - & 1 & Environmental \\
\hline 4 & Y. enterocolitica & Ye 4 & + & + & 1 & Environmental \\
\hline 5 & Y. enterocolitica & Ye 5 & + & + & 1 & Environmental \\
\hline 6 & Y. enterocolitica & Ye 6 & + & + & 1 & Environmental \\
\hline 7 & Y. enterocolitica & Ye 7 & + & + & 1 & Environmental \\
\hline 8 & Y. enterocolitica & Ye 8 & + & + & 1 & Environmental \\
\hline 9 & Y. enterocolitica & Ye 9 & + & + & 1 & Environmental \\
\hline 10 & Y. enterocolitica & Ye 10 & + & + & 1 & Environmental \\
\hline 11 & Y. enterocolitica & Ye 11 & - & + & 1 & Environmental \\
\hline 12 & Y. enterocolitica & Ye 12 & + & - & 1 & Environmental \\
\hline 13 & Y. enterocolitica & Ye 13 & + & + & 1 & Environmental \\
\hline 14 & Y. enterocolitica & Ye 14 & + & + & 1 & Non-environmental \\
\hline 15 & Y. enterocolitica & Ye 15 & + & - & 1 & Environmental \\
\hline 16 & Y. enterocolitica & Ye 16 & + & + & 1 & Non-environmental \\
\hline 17 & Y. enterocolitica & Ye 17 & + & + & 1 & Environmental \\
\hline 18 & Y. enterocolitica & Ye 18 & + & + & 1 & Environmental \\
\hline 19 & Y. enterocolitica & Ye 19 & + & + & 1 & Environmental \\
\hline 20 & Y. enterocolitica & Ye 20 & + & + & 1 & Environmental \\
\hline 21 & Y. enterocolitica & Ye 21 & - & - & 1 & Environmental \\
\hline 22 & Y. enterocolitica & Ye 22 & + & + & 1 & Environmental \\
\hline 23 & Y. enterocolitica & Ye 23 & + & + & 1 & Environmental \\
\hline 24 & Y. enterocolitica & Ye 24 & - & + & 1 & Environmental \\
\hline 25 & Y. enterocolitica & Ye 25 & + & + & 1 & Environmental \\
\hline 26 & Y. enterocolitica & Ye 26 & + & + & 1 & Environmental \\
\hline 27 & Y. enterocolitica & Ye 27 & + & + & 1 & Environmental \\
\hline 28 & Y. enterocolitica & Ye 28 & + & + & 1 & Environmental \\
\hline 29 & Y. enterocolitica & Ye 29 & + & - & 1 & Environmental \\
\hline 30 & Y. enterocolitica & Ye 30 & + & - & 1 & Environmental \\
\hline 31 & Y. enterocolitica & Ye 31 & + & + & 1 & Environmental \\
\hline 32 & Y. enterocolitica & Ye 32 & - & + & 1 & Environmental \\
\hline 33 & Y. enterocolitica & Ye 33 & + & - & 1 & Environmental \\
\hline 34 & $Y$. enterocolitica & Ye 34 & + & + & 1 & Environmental \\
\hline 35 & Y.enterocolitica & Ye 35 & - & + & 1 & Environmental \\
\hline 36 & Y.enterocolitica & Ye 36 & + & + & 1 & Environmental \\
\hline 37 & Y.enterocolitica & Ye 37 & + & + & 1 & Environmental \\
\hline 38 & Y. enterocolitica & Ye 38 & + & + & 1 & Environmental \\
\hline 39 & Y. enterocolitica & Ye 39 & + & + & 1 & Environmental \\
\hline 40 & Y. enterocolitica & Ye 40 & + & + & 1 & Environmental \\
\hline 41 & Y. enterocolitica & Ye 41 & + & + & 1 & Environmental \\
\hline 42 & E. agglomerans & Ye 42 & - & - & 1 & Environmental \\
\hline 43 & Y. enterocolitica & Ye 43 & + & + & 1 & Environmental \\
\hline 44 & Y. enterocolitica & Ye 44 & + & + & 1 & Environmental \\
\hline 45 & Y. enterocolitica & Ye 45 & + & + & 1 & Environmental \\
\hline 46 & Y. enterocolitica & Ye 46 & + & - & 1 & Environmental \\
\hline 47 & Y. enterocolitica & Ye 20 & + & + & 1 & Environmental \\
\hline 48 & Y. enterocolitica & Ye 48 & + & - & 1 & Environmental \\
\hline 49 & Y. enterocolitica & Ye 49 & + & + & 1 & Environmental \\
\hline 50 & ?(Water isolate) & H-3 & - & + & 1 & Environmental \\
\hline 51 & ?(Water isolate) & $35-2$ & + & + & 1 & Environmental \\
\hline 52 & P. fluorescens & Ps 19 & - & - & 1 & Environmental \\
\hline 53 & Y. enterocolitica & $74-457$ & - & + & 2 & Non-environmental \\
\hline 54 & Y. enterocolitica & $74-458$ & - & + & 2 & Non-environmental \\
\hline
\end{tabular}

"Rhamnose and sucrose reactions, 4 days, $30^{\circ} \mathrm{C}$.

${ }^{b}$ Sources: 1, Original isolate, this laboratory; 2, Analytab Products, Inc., Plainview, N.Y.; 3, M. Bissett, Department of Health, Berkeley, Calif.; 4, B. Chester, Veterans Administration Hospital, Miami, Fla.; 5, M. J. Pickett, Microbiology Department, University of California, Los Angeles; 6, S. Hsu, Department of Public Health, Lansing, Mich. 
TABLE 1-continued

\begin{tabular}{|c|c|c|c|c|c|c|}
\hline \multirow[b]{2}{*}{ Serial no. } & \multicolumn{2}{|c|}{ Received as: } & \multicolumn{2}{|c|}{ Biovar $^{\prime \prime}$} & \multirow[b]{2}{*}{ Source $^{h}$} & \multirow[b]{2}{*}{ Habitat } \\
\hline & Species & $\begin{array}{l}\text { Strain designa- } \\
\text { tion }\end{array}$ & Rhamnose & Sucrose & & \\
\hline 55 & Y. enterocolitica & $74-459$ & - & + & 2 & Non-environmental \\
\hline 56 & Y. enterocolitica & $74-461$ & - & - & 2 & Non-environmental \\
\hline 57 & Y. enterocolitica & $74-463$ & + & + & 2 & Non-environmental \\
\hline 58 & Y. enterocolitica & $74-593$ & - & + & 2 & Non-environmental \\
\hline 59 & Y. enterocolitica & $74-702$ & - & + & 2 & Non-environmental \\
\hline 60 & Y. enterocolitica & $7 \overline{4-780}$ & - & + & 2 & Non-environmental \\
\hline 61 & Y. enterocolitica & $74-939$ & - & + & 2 & Non-environmental \\
\hline 62 & Y. enterocolitica & $74-940$ & - & + & 2 & Non-environmental \\
\hline 63 & Y. enterocolitica & $74-941$ & - & + & 2 & Non-environmental \\
\hline 64 & Y. enterocolitica & $74-942$ & - & + & 2 & Non-environmental \\
\hline 65 & Y. enterocolitica & $74-1875$ & - & + & 2 & Non-environmental \\
\hline 66 & Y. enterocolitica & 74-984 & - & + & 2 & Non-environmental \\
\hline 67 & Y. enterocolitica & $74-983$ & - & + & 2 & Non-environmental \\
\hline 68 & Y. enterocolitica & $74-982$ & - & + & $\overline{2}$ & Non-environmental \\
\hline 69 & Y. enterocolitica & $74-981$ & - & + & 2 & Non-environmental \\
\hline 70 & Y. enterocolitica & $74-979$ & - & + & 2 & Non-environmental \\
\hline 71 & Y. enterocolitica & $74-978$ & - & + & 2 & Non-environmental \\
\hline 72 & Y. enterocolitica & $74-975$ & - & + & $\overline{2}$ & Non-environmental \\
\hline 73 & Y. enterocolitica & $74-974$ & - & + & 2 & Non-environmental \\
\hline 74 & Y. enterocolitica & $74-973$ & - & + & 2 & Non-environmental \\
\hline 75 & Y. enterocolitica & $74-972$ & - & + & 2 & Non-environmental \\
\hline 76 & Y. enterocolitica & $74-971$ & - & + & 2 & Non-environmental \\
\hline 77 & Y. enterocolitica & $74-970$ & - & + & 2 & Non-environmental \\
\hline 78 & Y. enterocolitica & $74-969$ & - & + & 2 & Non-environmental \\
\hline 79 & Y. enterocolitica & $74-968$ & - & + & 2 & Non-environmental \\
\hline 80 & Y. enterocolitica & $74-967$ & - & + & 2 & Non-environmental \\
\hline 81 & Y. enterocolitica & $74-966$ & - & + & 2 & Non-environmental \\
\hline 82 & Y. enterocolitica & $74-965$ & - & + & 2 & Non-environmental \\
\hline 83 & Y. enterocolitica & $74-964$ & - & + & 2 & Non-environmental \\
\hline 84 & Y. enterocolitica & $74-962$ & - & + & 2 & Non-environmental \\
\hline 85 & Y. enterocolitica & $74-960$ & - & + & 2 & Non-environmental \\
\hline 86 & Y. enterocolitica & 74-959 & - & + & 2 & Non-environmental \\
\hline 87 & Y. enterocolitica & $74-957$ & - & + & 2 & Non-environmental \\
\hline 88 & Y. enterocolitica & $74-956$ & - & + & 2 & Non-environmental \\
\hline 89 & Y. enterocolitica & $74-955$ & - & + & 2 & Non-environmental \\
\hline 90 & Y. enterocolitica & $74-954$ & - & + & 2 & Non-environmental \\
\hline 91 & Y. enterocolitica & $74-953$ & - & + & 2 & Non-environmental \\
\hline 92 & Y. enterocolitica & $74-952$ & - & + & 2 & Non-environmental \\
\hline 93 & Y. enterocolitica & $74-951$ & - & + & 2 & Non-environmental \\
\hline 94 & Y. enterocolitica & $74-950$ & - & + & 2 & Non-environmental \\
\hline 95 & $Y$. enterocolitica & $74-949$ & - & + & 2 & Non-environmental \\
\hline 96 & Y. enterocolitica & $74-947$ & - & + & 2 & Non-environmental \\
\hline 97 & Y. enterocolitica & $74-946$ & - & + & 2 & Non-environmental \\
\hline 98 & Y. enterocolitica & $74-945$ & - & + & 2 & Non-environmental \\
\hline 99 & $Y$. enterocolitica & $74-944$ & - & + & 2 & Non-environmental \\
\hline 100 & Y. enterocolitica & $74-943$ & - & + & 2 & Non-environmental \\
\hline 101 & Y. enterocolitica & $74-1892$ & - & + & 2 & Non-environmental \\
\hline 102 & Y. enterocolitica & $75-169$ & - & + & 2 & Non-environmental \\
\hline 103 & Y. enterocolitica & $75-1199$ & - & + & 2 & Non-environmental \\
\hline 104 & Y. enterocolitica & $75-1200$ & - & + & 2 & Non-environmental \\
\hline 105 & Y. enterocolitica & $75-1201$ & - & + & 2 & Non-environmental \\
\hline 106 & Y. enterocolitica & $75-1202$ & - & + & 2 & Non-environmental \\
\hline 107 & Y. enterocolitica & $75-1203$ & - & + & 2 & Non-environmental \\
\hline 108 & Y. enterocolitica & $75-1205$ & - & + & 2 & Non-environmental \\
\hline 109 & Y. enterocolitica & $75-1206$ & - & + & 2 & Non-environmental \\
\hline 110 & $Y$. enterocolitica & $75-1207$ & - & + & 2 & Non-environmental \\
\hline 111 & Y. enterocolitica & $75-1208$ & - & + & 2 & Non-environmental \\
\hline 112 & $Y$. enterocolitica & $75-1210$ & - & + & 2 & Non-environmental \\
\hline 113 & Y. enterocolitica & $75-1211$ & - & + & 2 & Non-environmental \\
\hline
\end{tabular}


TABLE 1-continued

\begin{tabular}{|c|c|c|c|c|c|c|}
\hline \multirow[b]{2}{*}{ Serial no. } & \multicolumn{2}{|c|}{ Received as: } & \multicolumn{2}{|c|}{ Biovar $^{a}$} & \multirow[b]{2}{*}{ Source ${ }^{b}$} & \multirow[b]{2}{*}{ Habitat } \\
\hline & Species & $\begin{array}{c}\text { Strain designa- } \\
\text { tion }\end{array}$ & Rhamnose & Sucrose & & \\
\hline 114 & Y. enterocolitica & $75-1212$ & - & + & 2 & Non-environmental \\
\hline 115 & Y. enterocolitica & $75-1213$ & - & + & 2 & Non-environmental \\
\hline 116 & Y. enterocolitica & $75-1214$ & - & + & 2 & Non-environmental \\
\hline 117 & Y. enterocolitica & $75-1215$ & - & - & 2 & Non-environmental \\
\hline 118 & Y. enterocolitica & $75-1216$ & - & - & 2 & Non-environmental \\
\hline 119 & Y. enterocolitica & $75-1217$ & - & - & 2 & Non-environmental \\
\hline 120 & Y. enterocolitica & $75-1218$ & - & - & 2 & Non-environmental \\
\hline 121 & Y. enterocolitica & $75-1219$ & - & - & $\overline{2}$ & Non-environmental \\
\hline 122 & Y. enterocolitica & $75-1220$ & - & + & 2 & Non-environmental \\
\hline 123 & Y. enterocolitica & $75-1221$ & - & + & 2 & Non-environmental \\
\hline 124 & Y. enterocolitica & $75-1222$ & - & + & 2 & Non-environmental \\
\hline 125 & Y. enterocolitica & $75-1223$ & - & - & 2 & Non-environmental \\
\hline 126 & Y. enterocolitica & $75-1224$ & + & + & 2 & Environmental \\
\hline 127 & Y. enterocolitica & $75-1225$ & + & + & 2 & Environmental \\
\hline 128 & Y. enterocolitica & $75-1226$ & - & + & 2 & Non-environmental \\
\hline 129 & Y. enterocolitica & $75-1227$ & - & + & 2 & Non-environmental \\
\hline 130 & Y. enterocolitica & $75-1228$ & - & + & 2 & Non-environmental \\
\hline 131 & Y. enterocolitica & $75-1229$ & - & + & 2 & Environmental \\
\hline 132 & Y. enterocolitica & $75-1231$ & - & + & 2 & Non-environmental \\
\hline 133 & Y. enterocolitica & $75-1335$ & - & + & 2 & Non-environmental \\
\hline 134 & Y. enterocolitica & $75-1531$ & - & + & 2 & Non-environmental \\
\hline 135 & Y. enterocolitica & $75-1538$ & - & + & 2 & Non-environmental \\
\hline 136 & Y. enterocolitica & $75-1763$ & - & + & 2 & Non-environmental \\
\hline 137 & Y.enterocolitica & Ye 137 & + & + & 1 & Environmental \\
\hline 138 & Y. enterocolitica & Ye 138 & - & - & 1 & Environmental \\
\hline 139 & Y. enterocolitica & $75-1806$ & - & + & 2 & Non-environmental \\
\hline 140 & Y. enterocolitica & $75-1896$ & - & + & 2 & Non-environmental \\
\hline 141 & Y. enterocolitica & $75-2360$ & - & + & 2 & Non-environmental \\
\hline 142 & Y. enterocolitica & $75-2361$ & - & + & 2 & Non-environmental \\
\hline 143 & Y. enterocolitica & $107 \mathrm{~A}$ & - & + & 3 & Non-environmental \\
\hline 144 & Y. enterocolitica & $107 \mathrm{~B}$ & - & + & 3 & Non-environmental \\
\hline 145 & Y. enterocolitica & $107 \mathrm{C}$ & - & + & 3 & Non-environmental \\
\hline 146 & Y. enterocolitica & $107 \mathrm{D}$ & - & + & 3 & Non-environmental \\
\hline 147 & Y. enterocolitica & $107 \mathbf{E}$ & - & + & 3 & Non-environmental \\
\hline 148 & Y. enterocolitica & $107 \mathrm{~F}$ & - & + & 3 & Non-envirońmental \\
\hline 149 & Y. enterocolitica & $107 \mathrm{G}$ & - & + & 3 & Non-environmental \\
\hline 150 & Y. enterocolitica & $107 \mathrm{H}$ & - & + & 3 & Non-environmental \\
\hline 151 & Y. enterocolitica & $107 \mathrm{I}$ & - & + & 3 & Non-environmental \\
\hline 152 & Y. enterocolitica & $107 \mathrm{~J}$ & - & + & 3 & Non-environmental \\
\hline 153 & Y. enterocolitica & $107 \mathrm{~K}$ & - & - & 3 & Non-environmental \\
\hline 154 & Y. enterocolitica & $107 \mathrm{~L}$ & - & - & 3 & Non-environmental \\
\hline 155 & Y. enterocolitica & $107 \mathrm{M}$ & - & + & 3 & Non-environmental \\
\hline 156 & Y. enterocolitica & $107 \mathrm{~N}$ & - & + & 3 & Non-environmental \\
\hline 157 & Y. enterocolitica & 1070 & - & + & 3 & Non-environmental \\
\hline 158 & Y. enterocolitica & $107 \mathrm{P}$ & + & + & 3 & Non-environmental \\
\hline 159 & Y. enterocolitica & $107 \mathrm{Q}$ & + & + & 3 & Environmental \\
\hline 160 & Y. enterocolitica & $107 \mathrm{R}$ & - & + & 3 & Non-environmental \\
\hline 161 & Y. enterocolitica & $107 \mathrm{~S}$ & - & + & 3 & Non-environmental \\
\hline 162 & Y. enterocolitica & $107 \mathrm{~T}$ & - & + & 3 & Non-environmental \\
\hline 163 & Y. enterocolitica & $107 \mathrm{U}$ & - & - & 3 & Environmental \\
\hline 164 & Y. enterocolitica & Ye 164 & - & + & 1 & Non-environmental \\
\hline 165 & Y. enterocolitica & Ye 165 & - & + & 1 & Non-environmental \\
\hline 166 & Y. enterocolitica & Ye 166 & + & + & 1 & Environmental \\
\hline 167 & Y. enterocolitica & Ye 167 & + & + & 1 & Environmental \\
\hline 168 & Y. enterocolitica & Ye 168 & - & - & 1 & Environmental \\
\hline 169 & Y. enterocolitica & Ye 169 & + & + & $i$ & Environmental \\
\hline 170 & Y. enterocolitica & Ye 170 & + & + & 1 & Environmental \\
\hline 171 & Y. enterocolitica & Ye 171 & + & + & 1 & Environmental \\
\hline
\end{tabular}


TABLE 1-continued

\begin{tabular}{|c|c|c|c|c|c|c|}
\hline \multirow[b]{2}{*}{ Serial no. } & \multicolumn{2}{|c|}{ Received as: } & \multicolumn{2}{|c|}{ Biovar $^{a}$} & \multirow[b]{2}{*}{ Source $^{b}$} & \multirow[b]{2}{*}{ Habitat } \\
\hline & Species & $\begin{array}{c}\text { Strain designa- } \\
\text { tion }\end{array}$ & Rhamnose & Sucrose & & \\
\hline 172 & Y. enterocolitica & Ye 172 & + & + & 1 & Environmental \\
\hline 173 & Y. enterocolitica & Ye 173 & - & - & 1 & Environmental \\
\hline 174 & Y. enterocolitica & Ye 174 & - & - & 1 & Environmental \\
\hline 175 & Y. enterocolitica & Ye 175 & + & + & 1 & Environmental \\
\hline 176 & Y. enterocolitica & Ye 176 & - & - & 1 & Environmental \\
\hline 177 & Y. enterocolitica & Ye 1-L & + & + & 1 & Environmental \\
\hline 178 & Y. enterocolitica & Ye 167-L & + & + & 1 & Environmental \\
\hline 179 & Y. enterocolitica & Ye-49 & + & + & 4 & Non-environmental \\
\hline 180 & Y. enterocolitica & $Y-48$ & + & + & 4 & Non-environmental \\
\hline 181 & Y. enterocolitica & Y-50 & + & + & 4 & Non-environmental \\
\hline 182 & Y. enterocolitica & $Y-51$ & + & + & 4 & Non-environmental \\
\hline 183 & Y. enterocolitica & $\mathrm{Y}-53$ & + & + & 4 & Non-environmental \\
\hline 184 & Y. enterocolitica & Y-54 & + & + & 4 & Non-environmental \\
\hline 185 & $Y$. enterocolitica & Y-55 & + & + & 4 & Non-environmental \\
\hline 186 & Y. enterocolitica & Y-56 & + & + & 4 & Non-environmental \\
\hline 187 & Y. enterocolitica & $Y-57$ & + & + & 4 & Non-environmental \\
\hline 188 & Y. enterocolitica & $Y-58$ & + & + & 4 & Non-environmental \\
\hline 189 & Y. enterocolitica & $Y-59$ & + & + & 4 & Non-environmental \\
\hline 190 & Y. enterocolitica & $\mathrm{Y}-60$ & + & + & 4 & Non-environmental \\
\hline 191 & Y. enterocolitica & $Y-61$ & + & + & 4 & Non-environmental \\
\hline 192 & C. diversus & $\mathrm{Y}-\mathrm{U}$ & + & + & 5 & Non-environmental \\
\hline 193 & Y. enterocolitica & Ye A & + & + & 6 & Environmental \\
\hline 194 & Y. enterocolitica & Ye E & + & + & 6 & Environmental \\
\hline 195 & Y. enterocolitica & Ye $\mathrm{H}$ & - & - & 6 & Environmental \\
\hline
\end{tabular}

pale pink to rose color around the inoculum was recorded as a positive result.

Alkalinization and/or growth on Simmons citrate agar at $24 \mathrm{~h}$ or 7 days was scored as a positive result.

Catalase and oxidase tests were performed with 24 $h$-old growth from heart infusion agar plates. The oxidase test was performed by rubbing a loopful of cell paste onto a moistened strip of filter paper previously saturated with a solution of $1 \%$ tetramethyl-p-phenylenediamine dihydrochloride in $0.2 \%$ ascorbic acid. Development of a purple color within $10 \mathrm{~s}$ was read as positive for cytochrome $c$ oxidase. For detection of catalase activity, the plates were flooded with $3 \% \mathrm{H}_{2} \mathrm{O}_{2}$, and the appearance of bubbles was recorded as a positive result.

Motility and indole production were both scored from motility indole ornithine medium (Difco). A tube of medium was stabbed to the bottom, and motility was read as diffusion of growth from the initial stab line. Indole was detected at $24 \mathrm{~h}$ with Kovacs reagent. Ornithine decarboxylation was also recorded in this medium, but the results were not used in the numerical analysis.

Moeller medium (19) supplemented with ornithine, lysine, or arginine (1\%, wt/vol), along with an unsupplemented control tube, was used to score decarboxylase activity. Tubes were inoculated and covered with a layer of mineral oil.

To detect hydrolysis of Tweens $20,40,60$, and 80 (Sigma Chemical Co.), a $1 \%$ (vol/vol, final concentration) solution of the appropriate Tween was added to a medium composed of $10 \mathrm{~g}$ of peptone (Difco), $5 \mathrm{~g}$ of
$\mathrm{NaCl}, 0.1 \mathrm{~g}$ of $\mathrm{CaCl}_{2} \cdot \mathrm{H}_{2} \mathrm{O}, 15 \mathrm{~g}$ of agar, and 1 liter of distilled water ( $\mathrm{pH}$ 7.4). Zones of precipitation were recorded for 5 days.

Double-strength heart infusion agar was autoclaved, cooled, and then added to an equal volume of an autoclaved skim milk solution ( $15 \%$, wt/vol). After mixing, this medium was poured into petri dishes, inoculated, and observed for clearing as evidence of casein hydrolysis. The test was terminated at 1 week.

Tributyrin hydrolysis was detected on a medium composed of heart infusion agar to which tributyrin $(1 \%, \mathrm{vol} / \mathrm{vol})$ was added and emulsified after autoclaving.

Phenylalanine agar (Difco) was inoculated and incubated for 2 days. Each slant was then flooded with an aqueous ferric chloride solution (13\%, wt/vol); development of a green color was read as a positive result.

Two methods were used for the detection of gelatin hydrolysis. (i) Nutrient gelatin (5 $\mathrm{g}$ of peptone [Difco], $3 \mathrm{~g}$ of beef extract [Difco], $120 \mathrm{~g}$ of gelatin [Difco], 1 liter of distilled water) was dispensed in 3$\mathrm{ml}$ amounts into tubes $(13$ by $100 \mathrm{~mm})$, autoclaved, inoculated, and incubated; liquefaction was recorded at 7 days and 4 weeks. (ii) Sterile heart infusion agar containing gelatin $(12 \%$, vol/vol; [Difco]) was poured into petri plates and inoculated; zones of hydrolysis were detected by flooding with aqueous mercuric chloride $(10 \%$, wt/vol) after incubation for 7 days.

The production of hydrogen sulfide from cystine was tested in a medium containing $10 \mathrm{~g}$ of Trypticase (BBL), $0.2 \mathrm{~g}$ of L-cystine, $5 \mathrm{~g}$ of sodium chloride, $0.2 \mathrm{~g}$ 
of ferric ammonium citrate, $2 \mathrm{~g}$ of agar, and 1 liter of distilled water. The medium was dispensed in 4-ml amounts into tubes ( 13 by $100 \mathrm{~mm}$ ) and inoculated by stabbing to the bottom.

Lipase and lecithinase activities were recorded from inoculations on egg yolk agar (Difco).

Starch hydrolysis was detected on heart infusion agar supplemented with cornstarch $(1 \%$, wt/vol). After 7 days of incubation, zones of hydrolysis were enhanced by flooding the plates with Gram iodine.

The methyl red and Voges-Proskauer tests were performed by incubating inoculated tubes of buffered glucose-peptone broth for $48 \mathrm{~h}$ and then dividing the broth for use in the two tests. The medium and reagents for these tests were as outlined in the Laboratory Manual for Medical Bacteriology, 5th ed. (16).

Nitrate reduction was tested in a broth composed of $10 \mathrm{~g}$ of a pancreatic digest of casein (Difco), $3 \mathrm{~g}$ of yeast extract, $2 \mathrm{~g}$ of potassium nitrate, and 1 liter of distilled water. After $24 \mathrm{~h}$ of incubation of the inoculated medium, nitrite formation was detected by using the method described in the Laboratory Manual for Medical Bacteriology.

The test for beta-galactosidase activity was done with tableted medium from Key Scientific Products Co., Los Angeles, Calif. Inoculum for the test was obtained by harvesting 18-h-old growth from a Kligler iron agar slant. The test was performed according to the recommendations of the manufacturer.

Kligler iron agar (Difco) supplemented with esculin $(0.002 \%$, wt/vol; Difco), lysine iron agar (Difco), Selenite-F broth (BBL Microbiology Systems), Rogosa agar (Difco), malonate broth (Difco), and tetrathionate broth (Difco) were also used. None of the results from the tests in which these media were employed was scored for numerical analysis, however, because of equivocal or duplicate results. Unless otherwise noted, all tests were read at $24 \mathrm{~h}$ and 4 days.

(vi) Coding of characters. All tests performed resulted potentially in mutually exclusive character states. Consequently, characters were scored 1 (positive) or 0 (negative). Weakly positive results were scored 1. Gas production from carbohydrates was not scored for numerical taxonomy.

Computation. All computations were computer directed by programs included in the "Numerical Taxonomy System of Multivariate Statistical Programs." These programs were developed at the University of Kansas and refined at the State University of New York at Stony Brook by F. James Rohlf, John Kishpaugh, and David Kirk. From the coefficients offered by this program, the simple matching coefficient was chosen on the basis of a recent comparative study (1) which showed this coefficient to be one of the most useful for differentiating clusters. Unweighted pair group method with averages was chosen from the several types of sequential agglomerative hierarchical cluster analyses offered by the program Taxon. This method of determining and graphically depicting the relationships among strains is recommended by the "Numerical Taxonomy System of Multivariate Statistical Programs" as the option of choice.

DNA hybridizations. (i) Bacterial strains. The centrostrains of the phenons from both the 30 and $35^{\circ} \mathrm{C}$ matrixes were used as reference strains in the subsequent DNA-DNA hybridization experiments.
Centrostrain is defined here as the bacterial strain within each cluster which has the highest mean relationship to every other organism in that cluster. In addition, two other organisms from each phenon were selected as sources of cold DNA for hybridizations. These organisms were chosen on the basis of their phenetic relationships to the centrostrains. One organism of each pair was highly related (similarity coefficient, $\geq 0.90$ ) to the centrostrain, whereas the other had the lowest similarity coefficient in comparison with the centrostrain for any organism of the cluster. The DNAs from additional organisms were labeled and/or extracted as deemed necessary for the adjunct genetic study of the environmental strains.

(ii) Media. Bacteria to be labeled were grown in a glucose salts medium containing $10 \mathrm{ml}$ of $10 \times$ salts, 5 $\mathrm{ml}$ of $10 \%$ (wt/vol) Casamino Acids (Difco), $0.1 \mathrm{ml}$ of $0.1 \mathrm{M} \mathrm{MgSO}_{4}, 1 \mathrm{ml}$ of $20 \%$ (wt/vol) glucose, and distilled water to $100 \mathrm{ml}$. The $10 \times$ salts solution was composed of $4.0 \mathrm{~g}$ of $\mathrm{KH}_{2} \mathrm{PO}_{4}, 10.5 \mathrm{~g}$ of $\mathrm{K}_{2} \mathrm{HPO}_{4}, 0.47$ $\mathrm{g}$ of sodium citrate $5 \mathrm{H}_{2} \mathrm{O}, 1.0 \mathrm{~g}$ of $\left(\mathrm{NH}_{4}\right)_{2} \mathrm{SO}_{4}$, and distilled water to $100 \mathrm{ml}$. Other bacteria were grown in Brucella broth (Difco).

(iii) DNA isolation. An overnight Brucella broth (Difco) culture $(10 \mathrm{ml}$ ) was added to $500 \mathrm{ml}$ of fresh medium and incubated with shaking at $30^{\circ} \mathrm{C}$ for 10 to $12 \mathrm{~h}$. Cells were harvested by centrifugation and then resuspended in $50 \mathrm{ml}$ of saline-ethylenediaminetetraacetate $(0.15 \mathrm{M} \mathrm{NaCl}$ plus $0.1 \mathrm{M}$ ethylenediaminetetraacetate, $\mathrm{pH} 8.0$ ). A 1-ml amount of $25 \%$ (wt/vol) sodium dodecyl sulfate and $2.5 \mathrm{mg}$ of pronase (B grade; nuclease free; Calbiochem) were added, and the mixture was incubated overnight at $35^{\circ} \mathrm{C}$. The subsequent isolation and purification technique was essentially that described by Marmur (17). The only modifications were the addition of several more purification steps. After completion of the Marmur technique, isolated DNA was subjected to an additional ribonuclease step, which was followed by repeated (three or four) deproteinizations before a final reprecipitation in isopropyl alcohol. The purified DNA was stored in dilute saline citrate $(0.1 \times \mathrm{SSC} ; 1 \times \mathrm{SSC}$ is $0.15 \mathrm{M} \mathrm{NaCl}$ plus $0.015 \mathrm{M}$ trisodium citrate, $\mathrm{pH} 7.0$ ) over chloroform at $4^{\circ} \mathrm{C}$.

(iv) Preparation of radioactive DNA. Radioactive DNA was produced by adding $10 \mathrm{ml}$ of an overnight glucose salts broth culture to $490 \mathrm{ml}$ of fresh glucose salts broth containing $72 \mu \mathrm{g}$ of [methyl $-{ }^{3} \mathrm{H}$ ] thymidine $(6.7 \mathrm{Ci} / \mathrm{mmol}$; New England Nuclear Corp., Boston, Mass.). The flask cultures were incubated with shaking at $30^{\circ} \mathrm{C}$ for 16 to $18 \mathrm{~h}$. Cells were harvested, and the DNA was extracted and purified as described above. All DNA concentrations were determined by using a Beckman model 22 spectrophotometer (Beckman Instruments, Inc., Scientific Instruments Div., Irvine, Calif.) at $260 \mathrm{~nm}$ and a standard curve.

DNA-DNA hybridizations. Numbered microfilters (diameter, $6 \mathrm{~mm}$ ) were punched from filter membranes (type HAWP; Millipore Corp., Bedford, Mass.) and soaked in $6 \times \mathrm{SSC}$ for 3 to $4 \mathrm{~h}$. Solutions of DNA in $0.1 \times \mathrm{SSC}$ were denatured for $10 \mathrm{~min}$ in a boiling water bath, chilled quickly on ice, and made up to $6 \times$ SSC. Microfilters were individually placed in a specially designed filter apparatus with a working diameter of $5 \mathrm{~mm}$. After the filters were washed with $6 \times$ 
SSC, solutions containing $10 \mu \mathrm{g}$ of denatured DNA were slowly passed through them (7). The filters were washed with additional $6 \times \mathrm{SSC}$ and were dried at room temperature overnight in a vacuum desiccator. Control filters were treated in the same manner except for DNA loading. The desiccator containing the filters was then placed in an $80^{\circ} \mathrm{C}$ oven for $2 \mathrm{~h}$.

Solutions $(1 \mathrm{ml})$ of radioactive reference DNA were sonically treated for $1 \mathrm{~min}$ in test tubes (diameter, 13 $\mathrm{mm}$ ) by using the microtip of a Sonifier cell disruptor (Ultrasonics, Inc., Plainview, N.Y.) at $40 \%$ intensity (9). Sonically treated DNA was denatured by heating as described above.

DNA-loaded filters and blank control filters were placed individually in test tubes (10 by $75 \mathrm{~mm}$ ) containing $0.2 \mathrm{ml}$ of $50 \%$ formamide (Matheson, Coleman, and Bell, Norwood, Ohio)-2× SSC, pH $7.0(9,15,18)$. With a digital microliter pipette (Pipetman; Cole Scientific, Calabasas, Calif.), $1 \mu \mathrm{g}$ of the appropriate reference DNA was added to each tube, and the tubes were incubated without shaking at a stringent temperature for this system $\left(40^{\circ} \mathrm{C}\right.$ for $\left.20 \mathrm{~h}\right)(15,18,20)$. Hybridizations were routinely done in triplicate. After incubation, filters were transferred to $50 \mathrm{ml}$ of $2 \times$ SSC-50\% formamide in a $100-\mathrm{ml}$ beaker and rinsed by magnetic stirring for $30 \mathrm{~min}$ at room temperature. This was followed by repeated (six to eight) manual rinses in small volumes of $2 \times \mathrm{SSC}$. The filters were dried in a $110^{\circ} \mathrm{C}$ oven for $3 \mathrm{~h}$ and counted in a Beckman model LS-3133P liquid scintillation system, using toluene-based scintillation fluid (Amersham).

Relative binding ratios (RBRs) were calculated for heterologous DNA strands by using the mean binding of homologous strands (in counts per minute) as $100 \%$. Counts per minute recorded from the blank control filters were subtracted from all counts before computation. Statistical evaluations of the fluctuations in counts per minute between replicate samples were performed by computation of the standard error of the mean for all samples.

\section{RESULTS}

Numerical taxonomy. The computer-generated phenograms based on the application of simple matching coefficients and the unweighted pair group method with averages to the test results are given in Fig. 1 and 2. At a similarity level of $85 \%$, the $35^{\circ} \mathrm{C}$ matrix formed five clusters of phenons (Fig. 1). If one compares the origins of strains as given in Table 1 with the $35^{\circ} \mathrm{C}$ phenogram, it is obvious that numerical analysis did not group the strains according to origin. Except for cluster 5, which is comprised solely of nonenvironmental strains, organisms from both environmental and nonenvironmental sources are represented in all clusters. However, if one analyzes these phenons as to biogroup, one sees a somewhat different picture. The 112 organisms in clusters 1 and 4, with only four exceptions in cluster 1, all belong to the so-called atypical rhamnose-positive group of $Y$. enterocolitica strains. Both typical (biovars 1 through 4 of Niléhn) and various atypical biogroups of $Y$.

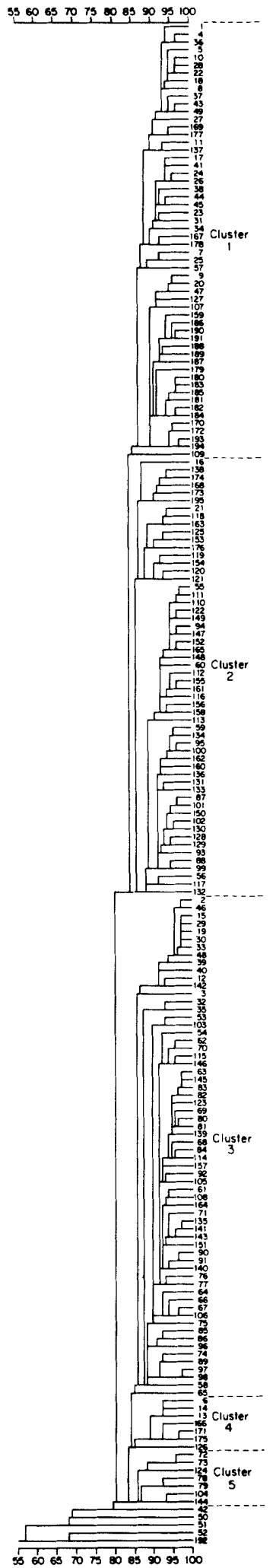

FIG. 1. $35^{\circ} \mathrm{C}$ phenogram. 


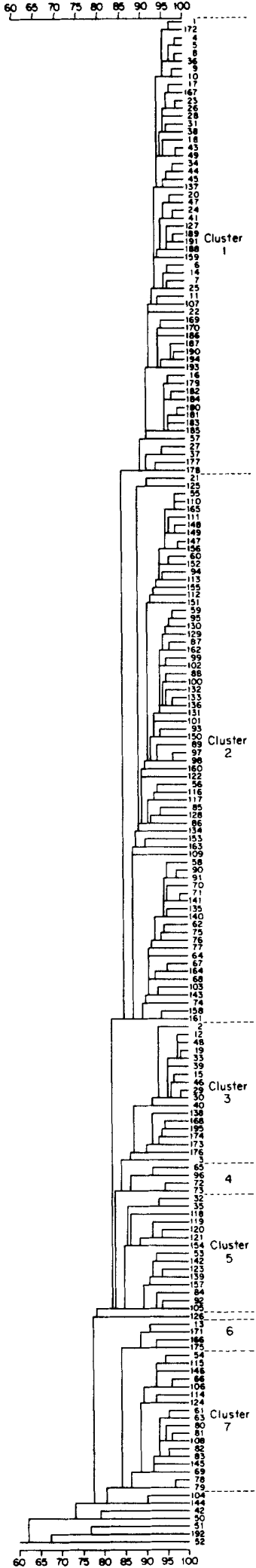

FIG. 2. $30^{\circ} \mathrm{C}$ phenogram. enterocolitica are represented in phenons 2 and 3 , with the typical biogroups predominating. The 56 organisms in phenon 2 are rhamnose negative with only two exceptions, both nonenvironmental isolates. In contrast, 11 of the environmental strains of cluster 3 belong to the atypical rhamnose-positive biogroup. Phenon 5 is composed of seven biochemically atypical strains of $Y$. enterocolitica, three of which are ornithine decarboxylase negative.

The phenogram in Fig. 2 represents an analysis of the results of test incubations at a temperature only $5^{\circ} \mathrm{C}$ lower than the temperature on which the phenogram in Fig. 1 was based, yet numerical analysis produced a different taxonomic ordering. Instead of five clusters at the $85 \%$ similarity level, there are seven. The relative arrangement of the 56 strains in cluster 1 changed considerably, but the overall composition remained fairly stable. Phenon 1 lost one of its rhamnose-negative organisms to phenon 2 and gained three of the atypical (rhamnose-positive) organisms which were in other clusters of the $35^{\circ} \mathrm{C}$ phenogram. This shift gives cluster 1 of the $30^{\circ} \mathrm{C}$ phenogram a composition of $95 \%$ atypical strains. Cluster 2 expanded to 70 organisms, gaining many of the typical $Y$. enterocolitica strains from cluster 3 of the $35^{\circ} \mathrm{C}$ phenogram and losing all but two of its environmental organisms. Phenon 3 of the $30^{\circ} \mathrm{C}$ phenogram is composed entirely of environmental organisms, both rhamnose positive and rhamnose negative. Phenon 4 is unremarkable except that two of the strains are ornithine decarboxylase negative. Phenons 5 and 7 are composed primarily of typical $Y$. enterocolitica strains from clusters 2 and 3 of the $35^{\circ} \mathrm{C}$ phenogram, although five sucrose-negative strains are in phenon 5 . Phenon 6 has all but one of the atypical environmental strains of cluster 4 of the $35^{\circ} \mathrm{C}$ phenogram. Three organisms (an atypical environmental strain and two nonenvironmental strains) are not associated with any of the clusters.

DNA hybridizations. Tables 2 and 3 give the results of the DNA hybridization studies within each cluster. Percent relatedness is expressed as the RBR of heterologous DNA to homologous DNA times 100. Also included in these tables are the phenetically generated relatedness values. In each case, this is the similarity coefficient expressed as percent relatedness.

If one examines the data presented for clusters 1 through 3 in Table 2, it becomes apparent that although there is high correlation between numerical analysis and DNA hybridization data when an organism has a high degree of phenetic relatedness to the centrostrain, the converse is true with a less highly related organism. In each of these cases, the organism which showed only 
TABLE 2. Percent relatedness of centrostrains to test strains

\begin{tabular}{ccccc}
\hline $35^{\circ} \mathrm{C}$ phenon no. & Centrostrain & Test strain & \% Similarity" & \% DNA binding \\
\hline 1 & 167 & 178 & 93 & 83 \\
& & 109 & 83 & 24 \\
2 & 112 & 161 & 95 & 100 \\
& & 16 & 84 & 27 \\
& & 114 & 95 & 99 \\
4 & 68 & 2 & 87 & 39 \\
& & 175 & 92 & 86 \\
5 & 166 & 126 & 92 & 94 \\
\end{tabular}

"Simple matching coefficient.

TABLE 3. Percent relatedness of centrostrains to test strains

\begin{tabular}{|c|c|c|c|c|}
\hline $30^{\circ} \mathrm{C}$ phenon no. & Centrostrain & Test strain & \% Similarity" & \% DNA binding \\
\hline \multirow[t]{2}{*}{1} & 191 & 189 & 97 & 96 \\
\hline & & 178 & 90 & 84 \\
\hline \multirow[t]{2}{*}{2} & 89 & 95 & 92 & 99 \\
\hline & & 161. & 87 & 80 \\
\hline \multirow[t]{2}{*}{3} & 29 & 30 & 99 & 73 \\
\hline & & 3 & 86 & 25 \\
\hline \multirow[t]{2}{*}{4} & 72 & 73 & 95 & 93 \\
\hline & & 65 & 86 & 92 \\
\hline \multirow[t]{2}{*}{5} & 53 & 142 & 93 & 94 \\
\hline & & 35 & 82 & 20 \\
\hline \multirow[t]{2}{*}{6} & 166 & 175 & 93 & 82 \\
\hline & & 171 & 88 & 23 \\
\hline \multirow[t]{2}{*}{7} & 63 & 61 & 95 & 63 \\
\hline & & 79 & 87 & 74 \\
\hline
\end{tabular}

"Simple matching coefficient.

a low degree of DNA relatedness was in a different phenon than the other two organisms in the $30^{\circ} \mathrm{C}$ matrix. Unfortunately, the same is true of clusters 4 and 5. Although all three organisms show a high degree of DNA relatedness, the one less related by numerical analysis in both clusters was placed in a different phenon than the other two in the $30^{\circ} \mathrm{C}$ matrix.

Clusters $1,2,4$, and 7 of the $30^{\circ} \mathrm{C}$ matrix in Table 3 show a high degree of correlation between numerical analysis and DNA hybridization data. With only two exceptions, however, the percent DNA relatedness is less than the corresponding numerical analysis relationship. Clusters 3,5 , and 6 exhibit the same phenomenon seen in the $35^{\circ} \mathrm{C}$ matrix. Organisms which have a high degree of relationship to the centrostrain by numerical analysis have good correlations with DNA relatedness values, whereas the less highly related organisms do not.

The results of DNA hybridization studies using the centrostrains from the 35 and $30^{\circ} \mathrm{C}$ matrixes are shown in Tables 4 and 5 . The centrostrains of clusters 1 and 4 and clusters 3 and 5 from Table 4 are obviously highly related by genetic data, as are those of clusters 1 and 6 and clusters 2, 4, 5, and 7 from Table 5 .

Table 6 presents the summation of all DNA hybridization studies along with the concomi-
TABLE 4. Percent relatedness of $35^{\circ} \mathrm{C}$ centrostrains, as determined by DNA hybridizations

\begin{tabular}{ccrrrr}
\hline \multirow{2}{*}{$\begin{array}{c}\text { Centrostrain of } \\
\text { phenon no. }\end{array}$} & \multicolumn{1}{c}{ \% Binding of centrostrain of phenon no.: } \\
\cline { 2 - 6 } & 1 & 2 & \multicolumn{1}{c}{3} & \multicolumn{1}{c}{4} & \multicolumn{1}{c}{5} \\
\hline 1 & 100 & 25 & 23 & 93 & 33 \\
2 & & 100 & 57 & 27 & 57 \\
3 & & & 100 & 21 & 98 \\
4 & & & & 100 & 29 \\
5 & & & & & 100 \\
\hline
\end{tabular}

TABle 5. Percent relatedness of $30^{\circ} \mathrm{C}$ centrostrains, as determined by DNA hybridizations

\begin{tabular}{ccrrrrrrr}
\hline & \multicolumn{8}{c}{ \% Binding } \\
$\begin{array}{c}\text { Centrostrain of } \\
\text { phenon no. }\end{array}$ & \multicolumn{6}{c}{ of centrostrain of phenon no.: } \\
\cline { 2 - 9 } & 1 & \multicolumn{1}{c}{2} & \multicolumn{1}{c}{3} & \multicolumn{1}{c}{4} & \multicolumn{1}{c}{5} & 6 & 7 \\
\hline 1 & 100 & 29 & 27 & 21 & 17 & 70 & 20 \\
2 & & 100 & 32 & 76 & 70 & 25 & 65 \\
3 & & & 100 & 27 & 24 & 26 & 19 \\
4 & & & & 100 & 83 & 30 & 89 \\
5 & & & & & 100 & 27 & 73 \\
6 & & & & & & 100 & 17 \\
7 & & & & & & & 100 \\
\hline
\end{tabular}

tant numerical analysis data. For comparative purposes, correlation ratios and the overall correlation coefficients have been computed for the genetic and phenetic percent relatedness figures. 
TABLE 6. Comparison of DNA hybridization and numerical taxonomy data

\begin{tabular}{|c|c|c|c|c|c|}
\hline \multirow{2}{*}{$\begin{array}{c}\text { Source of labeled DNA } \\
\text { (strain) }\end{array}$} & \multirow{2}{*}{$\begin{array}{c}\text { Source of unlabeled DNA } \\
\text { (strain) }\end{array}$} & \multirow{2}{*}{ \% Binding } & \multirow{2}{*}{$\begin{array}{c}\text { Standard error of } \\
\text { mean }\end{array}$} & \multicolumn{2}{|c|}{$\begin{array}{l}\text { \% Similarity when culture } \\
\text { incubated at: }{ }^{a}\end{array}$} \\
\hline & & & & $30^{\circ} \mathrm{C}$ & $35^{\circ} \mathrm{C}$ \\
\hline \multirow[t]{7}{*}{29} & 29 & 100 & 7.3 & 100 & 100 \\
\hline & 2 & 102 & 1.7 & 93 & 97 \\
\hline & 3 & 25 & 4.1 & 86 & 88 \\
\hline & 30 & 73 & 3.0 & 99 & 98 \\
\hline & 35 & 21 & 1.5 & 80 & 89 \\
\hline & 63 & 19 & 0.4 & 74 & 87 \\
\hline & 89 & 32 & 1.5 & 81 & 85 \\
\hline \multirow[t]{9}{*}{53} & 53 & 100 & 3.8 & 100 & 100 \\
\hline & 3 & 44 & 2.7 & 85 & 81 \\
\hline & 29 & 24 & 0.6 & 85 & 89 \\
\hline & 35 & 20 & 1.9 & 82 & 87 \\
\hline & 63 & 73 & 6.7 & 86 & 94 \\
\hline & 72 & 83 & 1.8 & 84 & 84 \\
\hline & 89 & 70 & 0.4 & 86 & 85 \\
\hline & 142 & 94 & 4.4 & 93 & 90 \\
\hline & 191 & 17 & 2.4 & 74 & 72 \\
\hline \multirow[t]{3}{*}{63} & 63 & 100 & 3.8 & 100 & 100 \\
\hline & 61 & 63 & 2.0 & 95 & 94 \\
\hline & 79 & 74 & 9.3 & 87 & 85 \\
\hline \multirow[t]{7}{*}{68} & 68 & 100 & 6.6 & 100 & 100 \\
\hline & 2 & 39 & 3.0 & 85 & 87 \\
\hline & 3 & 48 & 1.4 & 84 & 83 \\
\hline & 35 & 36 & 1.8 & 85 & 94 \\
\hline & 78 & 98 & 2.9 & 78 & 85 \\
\hline & 114 & 99 & 1.6 & 82 & 95 \\
\hline & 166 & 21 & 3.5 & 79 & 89 \\
\hline \multirow[t]{6}{*}{72} & 72 & 100 & 6.6 & 100 & 100 \\
\hline & 29 & 27 & 3.5 & 85 & 83 \\
\hline & 63 & 89 & 6.1 & 72 & 83 \\
\hline & 65 & 92 & 9.2 & 86 & 76 \\
\hline & 73 & 93 & 3.7 & 95 & 96 \\
\hline & 89 & 76 & 3.0 & 82 & 83 \\
\hline \multirow[t]{3}{*}{78} & 78 & 100 & 0.9 & 100 & 100 \\
\hline & 72 & 92 & 2.0 & 76 & 85 \\
\hline & 79 & 94 & 2.1 & 97 & 92 \\
\hline \multirow[t]{4}{*}{89} & 89 & 100 & 2.4 & 100 & 100 \\
\hline & 63 & 65 & 3.2 & 80 & 87 \\
\hline & 95 & 99 & 3.2 & 92 & 90 \\
\hline & 161 & 80 & 7.8 & 87 & 85 \\
\hline \multirow[t]{9}{*}{112} & 112 & 100 & 3.9 & 100 & 100 \\
\hline & 3 & 51 & 3.0 & 83 & 80 \\
\hline & 16 & 27 & 0.8 & 82 & 84 \\
\hline & 35 & 39 & 6.1 & 84 & 80 \\
\hline & 68 & 57 & 7.1 & 85 & 82 \\
\hline & 78 & 57 & 3.3 & 72 & 69 \\
\hline & 161 & 100 & 2.6 & 89 & 95 \\
\hline & 166 & 27 & 0.8 & 80 & 85 \\
\hline & 167 & 25 & 0.9 & 89 & 85 \\
\hline \multirow[t]{9}{*}{166} & 166 & 100 & 5.2 & 100 & 100 \\
\hline & 2 & 25 & 1.9 & 81 & 85 \\
\hline & 16 & 74 & 1.9 & 85 & 85 \\
\hline & 29 & 26 & 5.5 & 85 & 85 \\
\hline & 35 & 22 & 1.8 & 77 & 88 \\
\hline & 53 & 27 & 2.0 & 82 & 87 \\
\hline & 63 & 17 & 0.6 & 80 & 87 \\
\hline & 72 & 30 & 2.0 & 79 & 79 \\
\hline & 78 & 29 & 1.5 & 79 & 80 \\
\hline
\end{tabular}

" The coefficients of correlation were 0.48 and 0.40 for the 30 and $35^{\circ} \mathrm{C}$ data, respectively. The mean correlation ratios were 0.60 and 0.60 for the 30 and $35^{\circ} \mathrm{C}$ data, respectively. 
TABLE 6-continued

\begin{tabular}{|c|c|c|c|c|c|}
\hline \multirow{2}{*}{$\begin{array}{l}\text { Source of labeled DNA } \\
\text { (strain) }\end{array}$} & \multirow{2}{*}{$\begin{array}{c}\text { Source of unlabeled DNA } \\
\text { (strain) }\end{array}$} & \multirow{2}{*}{$\%$ Binding } & \multirow{2}{*}{$\begin{array}{c}\text { Standard error of } \\
\text { mean }\end{array}$} & \multicolumn{2}{|c|}{$\begin{array}{l}\text { \% Similarity when culture } \\
\text { incubated at: }\end{array}$} \\
\hline & & & & $30^{\circ} \mathrm{C}$ & $35^{\circ} \mathrm{C}$ \\
\hline & 89 & 25 & 1.0 & 84 & 85 \\
\hline & 126 & 86 & 5.4 & 83 & 86 \\
\hline & 167 & 92 & 7.6 & 89 & 87 \\
\hline & 171 & 23 & 2.2 & 88 & 94 \\
\hline & 175 & 82 & 2.6 & 93 & 92 \\
\hline & 191 & 70 & 4.4 & 85 & 81 \\
\hline \multirow[t]{6}{*}{167} & 167 & 100 & 7.8 & 100 & 100 \\
\hline & 68 & 23 & 1.8 & 85 & 82 \\
\hline & 78 & 33 & 1.9 & 72 & 74 \\
\hline & 109 & 24 & 1.7 & 86 & 83 \\
\hline & 166 & 94 & 5.6 & 89 & 87 \\
\hline & 178 & 83 & 6.0 & 95 & 93 \\
\hline \multirow[t]{8}{*}{191} & 191 & 100 & 7.2 & 100 & 100 \\
\hline & 3 & 37 & 2.2 & 76 & 76 \\
\hline & 29 & 27 & 0.6 & 83 & 75 \\
\hline & 63 & 20 & 1.0 & 66 & 72 \\
\hline & 72 & 21 & 1.2 & 81 & 71 \\
\hline & 89 & 29 & 0.9 & 82 & 78 \\
\hline & 178 & 84 & 7.5 & 90 & 84 \\
\hline & 189 & 96 & 5.0 & 97 & 94 \\
\hline \multirow[t]{6}{*}{195} & 195 & 100 & 7.6 & 100 & 100 \\
\hline & 2 & 44 & 4.2 & 89 & 86 \\
\hline & 3 & 89 & 6.6 & 88 & 86 \\
\hline & 29 & 42 & 1.8 & 87 & 85 \\
\hline & 35 & 60 & 4.4 & 83 & 84 \\
\hline & 191 & 43 & 1.8 & 80 & 85 \\
\hline
\end{tabular}

In addition, the standard error of the mean was calculated for all DNA hybridization results to illustrate concisely the amount of fluctuation in the raw data.

\section{DISCUSSION}

Numerical taxonomy involves counting the number of similar and dissimilar features between bacterial strains and resolving these by any of several formulas into similarity coefficients. With the aid of an electronic computer and an additional formula, strains were sorted into groups, based upon these similarity coefficients. The result is a graphic depiction of the degree of relatedness (based on observable features) among the strains tested. The chief criticism of this method is that it tests indirectly a relatively small portion of a bacterial genome. The most favorable estimates gauge the amount of a genome tested by numerical methods to be in the range of 10 to $20 \%(6)$. In contrast, DNA hybridization techniques theoretically offer a direct method of comparing the molecular structures of entire genomes.

Proponents of the numerical taxonomy approach have long argued that there should be (and in fact is) a high correlation between the evaluation of phenetic similarities and DNA ho- mologies. Their contention is that both reflect the similarity of base sequences and thus can be equated as techniques for determining relationships among organisms $(5,6,12)$. Unfortunately, this philosophy overlooks certain basic facts. Even though enzymes may perform the same function and thus be ranked as similarities in phenetic comparisons, the coding sequences of enzymes may differ, and thus the molecular structure of the DNA would differ. The choice and coding of features is also a problem in numerical taxonomy. Some taxonomies rely heavily on morphological features which, in addition to requiring qualitative judgements for coding, may also be the end results of the interaction of multiple enzymes. In addition, unless the individuals undertaking the study are very knowledgeable in bacterial physiology, a single feature can be weighted multiply. For example, in some genera of bacteria, a single enzyme is responsible for the oxidation of at least 10 carbohydrates to the corresponding sugar acids (2). If several or all of these sugars are included as test substrates for carbohydrate utilization by certain bacteria, the erroneous conclusion may be drawn that the ability to produce acid from each sugar attacked should be scored as a separate character. Observations such as these can result in a very biased 
picture of similarity relationships within a group. The mathematical approach of numerical taxonomy is sound, but the experimental data available for mathematical conversion are often the result of subjective decisions and genomic intrarelationships. The purity of the end can be obscured by the means.

This view was formed after the completion of the first phase of this study (the duplicate numerical taxonomies differing only in test incubation temperatures). Even a cursory comparison of the $35^{\circ} \mathrm{C}$ phenogram (Fig. 1) with the $30^{\circ} \mathrm{C}$ phenogram (Fig. 2) discloses a basic flaw of the method. The two phenograms differ considerably. If the organisms were accurately clustered by this method, a $5^{\circ} \mathrm{C}$ difference in incubation temperature should affect highly related strains in a homogeneous manner so that, although the relative order of the phenons might change, the individual cluster composition should remain basically stable. Experimentally, this was not the case. Statistical analysis of the $35^{\circ} \mathrm{C}$ data produced a phenogram of five clusters, whereas the $30^{\circ} \mathrm{C}$ data generated a phenogram with seven clusters plus three ungrouped organisms. Only cluster 1 remained relatively stable for the two phenograms. As the examples shown in Table 7 demonstrate, the members of this cluster typically exhibit higher intracluster similarity values at $30^{\circ} \mathrm{C}$ than at $35^{\circ} \mathrm{C}$. This, in combination with the knowledge that all $Y$. enterocolitica biovars are metabolically more active at the lower temperature, leads us to believe that the $30^{\circ} \mathrm{C}$ phenogram is the more accurate representation of taxonomic divisions within the groups. Unfortunately, however, the genetic evidence disputes this. The DNA hybridization study of the centrostrains from the $30^{\circ} \mathrm{C}$ phenogram (Table 5) justifies the existence of only three taxonomic divisions since the centrostrains of clusters 1 and 6 are highly related (RBR, $\geq 70 \%$ ), as are those of clusters $2,4,5$, and 7 . The $35^{\circ} \mathrm{C}$ phenogram does not fare much better by the same type of genetic comparison. As Table 4 shows, only a maximum of three of the five clusters of this matrix is confirmed by DNA hybridization evidence. In our opinion, all that has been elicited by the numerical taxonomies are subdivisions of these organisms into temperature-dependent biovars, with no discernment of the real genetic relationships among the various groups. The computer-aided statistical analysis has not increased our understanding of the true taxonomic interrelationships of this group of organisms past the biovar stage of Niléhn (21), which was achieved manually 10 years ago.

The methods of numerical taxonomy may separate organisms accurately into discrete taxa
TABLE 7. Comparative computer-generated similarity values of centrostrain of $30^{\circ} \mathrm{C}$ phenon 1 versus $30^{\circ} \mathrm{C}$ phenon 1 strains at 30 and $35^{\circ} \mathrm{C}$

\begin{tabular}{|c|c|c|}
\hline \multirow{2}{*}{ Comparison (strains) } & \multicolumn{2}{|c|}{ \% Similarity at: } \\
\hline & $30^{\circ} \mathrm{C}$ & $35^{\circ} \mathrm{C}$ \\
\hline $191 \times \quad 1$ & 92 & 87 \\
\hline $191 \times 172$ & 93 & 92 \\
\hline $191 \times 4$ & 92 & 86 \\
\hline $191 \times 5$ & 94 & 88 \\
\hline $191 \times 8$ & 92 & 90 \\
\hline $191 \times 36$ & 93 & 95 \\
\hline $191 \times 9$ & 95 & 94 \\
\hline $191 \times 10$ & 94 & 90 \\
\hline $191 \times 17$ & 94 & 87 \\
\hline $191 \times 167$ & 93 & 90 \\
\hline $191 \times 23$ & 92 & 85 \\
\hline $191 \times 26$ & 93 & 86 \\
\hline $191 \times 28$ & 94 & 90 \\
\hline $191 \times 31$ & 91 & 83 \\
\hline $191 \times 38$ & 91 & 84 \\
\hline $191 \times 18$ & 93 & 90 \\
\hline $191 \times 43$ & 92 & 86 \\
\hline $191 \times 49$ & 91 & 85 \\
\hline $191 \times 34$ & 93 & 85 \\
\hline $191 \times 44$ & 92 & 83 \\
\hline $191 \times 45$ & 91 & 83 \\
\hline $191 \times 137$ & 91 & 89 \\
\hline $191 \times 20$ & 95 & 91 \\
\hline $191 \times 47$ & 95 & 92 \\
\hline $191 \times 24$ & 94 & 87 \\
\hline $191 \times 41$ & 95 & 84 \\
\hline $191 \times 127$ & 97 & 93 \\
\hline $191 \times 189$ & 97 & 94 \\
\hline $191 \times 188$ & 96 & 92 \\
\hline $191 \times 159$ & 95 & 95 \\
\hline $191 \times 6$ & 91 & 82 \\
\hline $191 \times 14$ & 91 & 80 \\
\hline $191 \times 7$ & 92 & 90 \\
\hline $191 \times 25$ & 95 & 87 \\
\hline $191 \times 11$ & 93 & 87 \\
\hline $191 \times 107$ & 93 & 87 \\
\hline $191 \times 22$ & 93 & 89 \\
\hline $191 \times 169$ & 94 & 87 \\
\hline $191 \times 170$ & 90 & 92 \\
\hline $191 \times 186$ & 95 & 95 \\
\hline $191 \times 187$ & 93 & 92 \\
\hline $191 \times 190$ & 93 & 97 \\
\hline $191 \times 194$ & 95 & 93 \\
\hline $191 \times 193$ & 93 & 92 \\
\hline $191 \times 16$ & 93 & 85 \\
\hline $191 \times 179$ & 92 & 89 \\
\hline $191 \times 182$ & 92 & 92 \\
\hline $191 \times 184$ & 93 & 92 \\
\hline $191 \times 180$ & 92 & 92 \\
\hline $191 \times 181$ & 93 & 90 \\
\hline $191 \times 183$ & 92 & 94 \\
\hline $191 \times 185$ & 93 & 93 \\
\hline $191 \times 57$ & 91 & 92 \\
\hline $191 \times 27$ & 91 & 85 \\
\hline $191 \times 37$ & 90 & 84 \\
\hline $191 \times 177$ & 92 & 86 \\
\hline $191 \times 178$ & 89 & 84 \\
\hline $191 \times 178$ & 89 & 84 \\
\hline
\end{tabular}


when those organisms diverge radically when compared by the available testing procedures, but with organisms whose testable metabolic pathways are extremely similar, no valid conclusions can be drawn. The five control organisms, all obviously not $Y$. enterocolitica strains by superficial testing, separated out nicely on both phenograms. None showed a relationship to any of the $Y$. enterocolitica clusters at a similarity level higher than $78 \%$, and most linked at levels well below the 80 to $85 \%$ range considered analogous to species level by most advocates of numerical taxonomy (22). The $Y$. enterocolitica paired controls (strains 20 and 47, 1 and 177, 167 and 178 ) did not diverge radically at either temperature.

The criticism leveled here at the validity of establishing taxonomic divisions on the basis of phenetic clustering is based not only on the intrinsic errors of the testing procedures for numerical taxonomy but also on the results of comparisons with DNA hybridization data. DNA hybridization is theoretically much more valid for determining taxonomic relationships than is numerical taxonomy. Conceivably, however, the experimental error could offset this theoretical advantage. Unfortunately, few publications on DNA hybridization studies contain data on experimental error or mention whether replicate tests were used. Two studies which included replicate testing and standard error of the mean for the results are those of Garvie (8) and Gibbins and Gregory (9). Both studies used the membrane filter technique, but the incubation medium of Garvie was $2 \times$ SSC- $30 \%$ dimethyl sulfoxide instead of the $6 \times$ SSC-50\% formamide used in this study and in that of Gibbins and Gregory. The average standard error of the mean of Garvie was 4.8 (range, 0.01 to 27.4), whereas that of Gibbins and Gregory was 0.4 (range, 0.06 to 1.26 ). The average standard error of the mean of this study was 3.4 (range, 0.4 to 9.3 ); the fluctuation among replicate tests was greater than that found by Gibbins and Gregory but not as much as that noted by Garvie. The deviation in the replicate counts of Gibbins and Gregory, as evidenced by an overall standard error of the mean of 0.4 , is extraordinarily low. Even though the average standard error of the mean calculated for the Y. enterocolitica study was higher and thus the reproducibility was lower than that of the Gibbins and Gregory study, data from reciprocal hybridizations (Table 8) give considerable support to the validity of the method.

Additional support for the validity of the method derives from the fact that DNA hybridization measures the relationship of the molecular structure of the entire genome of one bac-
TABLE 8. Reciprocal DNA hybridizations

\begin{tabular}{cccc}
\hline Group & $\begin{array}{c}\text { Source of labeled } \\
\text { DNA (strain) }\end{array}$ & $\begin{array}{c}\text { Source of unlabeled } \\
\text { DNA (strain) }\end{array}$ & $\begin{array}{c}\% \\
\text { Binding }\end{array}$ \\
\hline 1 & 112 & 78 & 57 \\
& 112 & 68 & 57 \\
2 & 68 & 78 & 98 \\
& 112 & 166 & 27 \\
& 112 & 167 & 25 \\
3 & 166 & 167 & 92 \\
& 195 & 2 & 44 \\
& 195 & 29 & 42 \\
4 & 29 & 2 & 102 \\
& 166 & 2 & 25 \\
& 166 & 29 & 26 \\
5 & 29 & 2 & 102 \\
& 166 & 72 & 30 \\
& 166 & 78 & 29 \\
6 & 78 & 72 & 92 \\
& 167 & 78 & 33 \\
& 166 & 78 & 29 \\
7 & 167 & 166 & 94 \\
& 166 & 167 & 92 \\
& 167 & 166 & 94 \\
\hline
\end{tabular}

terium to that of another, whereas numerical taxonomy measures, at best, only $20 \%$ of the genome through phenotypic capabilities. When one evaluates this indirect measurement of $20 \%$ of the genome in terms of the error in test reproducibility plus the unknown error in inadvertent testing duplication, the disparity between the values of the two procedures for taxonomic purposes becomes even more obvious. Although Colwell and colleagues (6) derived correlation coefficients ranging from 0.5 to 0.9 in a comparison between a numerical taxonomy done in the laboratory of Colwell and DNA hybridizations done with some of the same strains in the laboratory of D. Brenner, these correlation coefficients are misleading. Omitted from the calculations were all matches where the percent similarity was $60 \%$ or less. This omitted many sets of aberrant data from the computations (for example, RBR of $71 \%$, percent similarity of $48 \%$; RBR of $70 \%$, percent similarity of $48 \%$; RBR of $70 \%$, percent similarity of $58 \%$; RBR of $73 \%$, percent similarity of $57 \%$ ). These data were taken from Colwell et al. (6), who compared Escherichia coli with Shigella species. All of the DNA hybridizations gave values which showed a species relationship, whereas numerical taxonomy indicated that these organisms are not significantly related.

In addition, the correlation coefficient $r$ is simply a measure of the linear relationship between two variables. It gives no indication of how closely related numerically these two variables are. In a comparison of numerical taxonomy similarity values to DNA hybridization ho- 
mologies, some indication of how closely related these values are numerically is desirable. As an indication of the misleading impression given by an $r$ value of 0.9 , consider the following data set taken from the study by Colwell et al. (6), in which Salmonella typhimurium was used as the reference organism against Citrobacter species, RBR of $58 \%$, percent similarity of $84 \%$; RBR of $58 \%$, percent similarity of $83 \%$; RBR of $50 \%$, percent similarity of $82 \%$; RBR of $49 \%$, percent similarity of $84 \%$; RBR of $49 \%$, percent similarity of $77 \%$; RBR of $46 \%$, percent similarity of $79 \%$; RBR of $46 \%$, percent similarity of $79 \%$; RBR of $42 \%$, percent similarity of $80 \%$. The data give a good linear correlation, as evidenced by the correlation coefficient of 0.9 for the set as a whole. However, in the examples shown, all of the percent similarity values denote a high phenetic relationship, whereas the RBRs indicate low DNA base sequence homology. If one assumes a significant taxonomic relationship at the $80 \%$ similarity level for numerical taxonomy (22) and at an RBR of $70 \%$ for DNA hybridization (3) and also assumes that phenetic similarity is a measure of genetic similarity, then one should expect both a high numerical correlation and a high linear correlation between the data sets. As can be seen by the comparative data generated in this study (Tables 2, 3, and 6) and by the examples just cited, this does not occur consistently. The average correlation ratio of 0.60 for both the 30 and $35^{\circ} \mathrm{C}$ data sets, as well as the overall correlation coefficients of 0.48 and 0.40 , respectively, are indicative of low numerical and linear correlations between numerical taxonomy and DNA hybridization.

Consideration of the final part of the study (determination of the intra- and interrelationships of the organisms from environmental sources) must depend on the results of DNA hybridizations. No coherent separations of this group of strains can be made on the basis of the numerical taxonomy results.

The one previous attempt at a comprehensive study of the species $Y$. enterocolitica was by Brenner et al. (3). The conclusions drawn from their study, which used an RBR of $70 \%$ or greater at stringent temperature as indicative of species relationship, were as follows: (i) the strains in their study formed three, possibly four, DNA relatedness groups; (ii) one DNA relatedness group biochemically is "typical" $Y$. enterocolitica, the second and third are rhamnose positive, the third is additionally melibiose, $\alpha$ methyl glucoside, and raffinose positive, and the possible fourth group is sucrose negative and rhamnose negative; (iii) all of the observed DNA relatedness groups should remain in the genus Yersinia, but only those organisms which are biochemically typical should be called $Y$. enterocolitica. The tenuousness of the fourth DNA relatedness group derived from the omission of hybridization of these strains to one of the rhamnose-positive groups plus the intermediate RBRs $(67,59$, and $55 \%)$ of the group 4 strains when hybridized to the group of typical $Y$. enterocolitica strains.

Except for data on two strains, our data agree with those in the above-mentioned study with respect to the DNA relatedness of typical $Y$. enterocolitica strains. The two aberrant strains (63 and 112) gave RBRs of less than $70 \%$ with some typical $Y$. enterocolitica strains and greater than $70 \%$ with others. Strain 112 had an RBR of 57\% with both strain 68 and strain 78 . These strains in turn had RBRs of greater than $70 \%$ with each other and with other typical strains. In contrast, strain 112 had an RBR of $100 \%$ with another typical $Y$. enterocolitica strain (strain 161), which subsequently hybridized with other strains of the biochemically typical group at RBR levels of greater than $70 \%$. Similar hybridization values occurred with strain 63. Hybridizing this strain with typical strains 61 and 69 resulted in RBR values of 63 and $65 \%$, respectively, whereas hybridization of all of these strains with other typical $Y$. enterocolitica strains resulted in RBR values of greater than $70 \%$. Unfortunately, strains 63 and 112 were not tested by hybridization to each other or to a common strain. Since ascertaining the DNA relatedness of typical Y. enterocolitica strains was not a goal of this study, the enigma was only fortuitously discovered by the interand intraphenon hybridizations. Johnson (11) proposed a subspecies designation for organisms that have 60 to $70 \%$ homology with organisms of the high homology group, and it may be that typical Y. enterocolitica strains 63 and 112 belong to a subspecies of $Y$. enterocolitica.

The results of hybridizations among the environmental organisms and between environmental and nonenvironmental strains of this study indicated the existence of three additional DNA relatedness groups. All of the groups can be characterized on the basis of their $30^{\circ} \mathrm{C}$ rhamnose and sucrose fermentation patterns: (i) rhamnose negative, sucrose positive; (ii) rhamnose negative, sucrose negative; (iii) rhamnose positive, sucrose positive; (iv) rhamnose positive, sucrose negative. Additional $30^{\circ} \mathrm{C}$ differential features of these groups are given in Table 9. This table also gives the total number of strains which, when cross-hybridized, comprised the respective relatedness groups. No attempt was made to categorize all of the strains in the study into the four groups.

The biochemical reactions of the four DNA 
TABLE 9. Differential features of Y. enterocolitica DNA relatedness groups

\begin{tabular}{|c|c|c|c|c|}
\hline \multirow[b]{2}{*}{ Characteristic } & \multicolumn{4}{|c|}{ Group ${ }^{a}$} \\
\hline & $\begin{array}{c}1 \\
(n=15)\end{array}$ & $\begin{array}{c}2 \\
(n=2)\end{array}$ & $\begin{array}{c}3 \\
(n=8)\end{array}$ & $\begin{array}{c}4 \\
(n=3)\end{array}$ \\
\hline \multicolumn{5}{|l|}{ Utilization of: } \\
\hline Rhamnose & - & - & + & + \\
\hline Sucrose & + & - & + & - \\
\hline Salicin & d & - & + & - \\
\hline Lactose & d & - & d & - \\
\hline Arbutin & $\bar{d}$ & - & + & - \\
\hline Cellobiose & + & + & + & - \\
\hline Raffinose & - & - & d & - \\
\hline Citrate (Simmons) & - & - & + & + \\
\hline Esculin hydrolysis & $\mathrm{d}$ & - & + & - \\
\hline Indole production & $d$ & - & + & - \\
\hline
\end{tabular}

${ }^{a}+$, All strains positive; - , all strains negative; $d$, different biochemical types.

relatedness groups of this study do not entirely conform to the four DNA relatedness groups of $Y$. enterocolitica identified by Brenner et al. (3). Based on comparative biochemical reactions, group 3 of this study is identical to their group 3 . Their other rhamnose-positive group (group 2) appears to have little biochemical relationship, other than the rhamnose reaction, to our group 4. Their potential group 4 (rhamnose and sucrose negative) may include both groups 2 and 4 of this study. The majority of biochemical reactions recorded by Brenner et al. were at $35^{\circ} \mathrm{C}$. At a temperature of $35^{\circ} \mathrm{C}$, group 4 of this study is rhamnose negative as well as sucrose negative. Their group 4 is comprised of organisms with different reactions in a variety of biochemical tests; these reactions conform to those of our groups 2 and 4 at $35^{\circ} \mathrm{C}$. Group 1 of both studies encompasses the biochemically typical Y. enterocolitica strains.

One environmental organism (strain 35) gave low RBR values with members of all DNA relatedness groups except group 2. With group 2, the relative homology value for this strain was $60 \%$. Again, it is difficult to interpret these intermediate values. Biochemically, this organism differs slightly from the members of group 2, giving reactions more compatible with those of members of group 1, the typical Y. enterocolitica strains. Cross-hybridizations with DNA from three members of this group, however, yielded RBR values of 20,36 , and $39 \%$. These ratios are indicative of a relationship no closer than genus level. If one adheres to the philosophy of Johnson (11), this is another example of subspecies relationship, this time within group 2. Another possible explanation, of course, is experimental error. The time involved in the several phases of DNA hybridization experiments precludes hybridizations between every pair of organisms in a study. Only further work by other investigators with different strains will result in a cohesive and complete picture of the taxonomic relationships within this group of organisms.

Based on this study and the study of Brenner et al. (3), it can be stated, however, that the strains presently identified as members of $Y$. enterocolitica comprise at least five DNA relatedness groups. One group contains the biochemically typical (rhamnose-negative, sucrose-positive) Y. enterocolitica strains. Two groups are rhamnose positive and sucrose positive. Brenner et al., differentiated these groups on the basis of their melibiose, methyl glucoside, and raffinose reactions; this study found only one DNA relatedness group of rhamnose-positive, sucrose-positive organisms. The fourth and fifth DNA relatedness groups contain sucrose-negative organisms. One group is rhamnose negative as well as sucrose negative, and the other is rhamnose positive. The level of intergroup homology is high enough (RBR, $>20 \%$ ) to justify the inclusion of all groups as species in the genus Yersinia unless subsequent work demonstrates greater homology between members of these new groups and another genus.

\section{ACKNOWLEDGMENT}

This research was supported in part by a grant from the Environmental Protection Agency.

\section{LITERATURE CITED}

1. Austin, B., and R. R. Colwell. 1977. Evaluation of some coefficients for use in numerical taxonomy of microorganisms. Int. J. Syst. Bacteriol. 27:204-210.

2. Baumann, P., M. Doudoroff, and R. Y. Stanier. 1968. A study of the Moraxella group. II. Oxidase-negative species (genus Acinetobacter). J. Bacteriol. 95:15201541.

3. Brenner, D. J., A. G. Steigerwalt, D. P. Falco, R. E. Weaver, and G. R. Fanning. 1976. Characterization of Yersinia enterocolitica and Yersinia pseudotuber. culosis by deoxyribonucleic acid hybridization and by biochemical reactions. Int. J. Syst. Bacteriol. 26:180194. 
4. Christensen, W. B. 1946. Urea decomposition as a means of differentiating Proteus and paracolon cultures from each other and from Salmonella and Shigella types. J. Bacteriol. 52:461-466.

5. Colwell, R. R. 1973. Genetic and phenetic classification of bacteria. Adv. Appl. Microbiol. 16:137-175.

6. Colwell, R. R., R. Johnson, L. Wan, T. E. Lovelace, and D. J. Brenner. 1974. Numerical taxonomy and deoxyribonucleic acid reassociation in the taxonomy of some gram-negative fermentative bacteria. Int. J. Syst. Bacteriol. 24:422-433.

7. De Ley, J., and R. Tijtgat. 1970. Evaluation of membrane filter methods for DNA-DNA hybridization. Antonie van Leeuwenhoek J. Microbiol. Serol. 36:461-474.

8. Garvie, E. I. 1976. Hybridization between the deoxyribonucleic acids of some strains of heterofermentative lactic acid bacteria. Int. J. Syst. Bacteriol. 26:116-122.

9. Gibbins, A. M., and K. F. Gregory. 1972. Relatedness among Rhizobium and Agrobacterium species determined by three methods of nucleic acid hybridization. J. Bacteriol. 111:129-141.

10. Harvey, S., J. R. Greenwood, M. J. Pickett, and R. A. Mah. 1976. Recovery of Yersinia enterocolitica from streams and lakes of California. Appl. Environ. Microbiol. 32:352-354.

11. Johnson, J. L. 1973. Use of nucleic acid homologies in the taxonomy of anaerobic bacteria. Int. J. Syst. Bacteriol. 23:308-315.

12. Jones, D., and P. H. A. Sneath. 1970. Genetic transfer and bacterial taxonomy. Bacteriol. Rev, 34:40-81.

13. Jordan, E. O., and P. H. Harmon. 1928. A new differential medium for the paratyphoid group. J. Infect. Dis. 42:238-241.
14. Knapp, W., and E. Thal. 1963. Untersuchungen über die kulturell-biochemischen, serologischen, tierexperimentellen und immunologischen Eigenschaften einer vorläufig "Pasteurella X" bennannten Bakterienart. Zentralbl. Bakteriol. Parasitenkd. Infektionskr. Hyg. Abt. 1 Orig. 190:472-484.

15. Kourilsky, P., J. Leidner, and G. Y. Tremblay. 1971. DNA-DNA hybridization on filters at low temperature in the presence of formamide or urea. Biochimie 53: 1111-1114.

16. Manclark, C. R., M. J. Pickett, and H. B. Moore. 1972. Laboratory manual for medical bacteriology, 5th ed. Appleton-Century-Crofts, New York.

17. Marmur, J. 1961. A procedure for the isolation of deoxyribonucleic acid from micro-organisms. J. Mol. Biol. 3: 208-218.

18. McConaughy, B. L., C. D. Laird, and B. J. McCarthy. 1969. Nucleic acid reassociation in formamide. Biochemistry 8:3289-3295.

19. Moeller, V. 1955. Simplified tests for some amino acid decarboxylases and for the arginine dihydrolase system. Acta Pathol. Microbiol. Scand. 36:158-172.

20. Moore, R. L., and R. R. Brubaker. 1975. Hybridization of deoxyribonucleotide sequences of Yersinia enteroco. litica and other selected members of Enterobacteriaceae. Int. J. Syst. Bacteriol. 25:336-339.

21. Niléhn, B. 1969. Studies on Yersinia enterocolitica with special reference to bacterial diagnosis and occurrence in human acute enteric disease. Acta Pathol. Microbiol. Scand. Suppl. 206:1-48.

22. Sneath, P. H. A., and R. R. Sokal. 1973. Principles of numerical taxonomy. W. H. Freeman \& Co., San Francisco. 